\title{
The Palm Date Treatment to Anaerobic Muscle Fatigue on Running Athlete
}

\author{
Mursid Tri Susilo \\ Public Health Science Department \\ Universitas Negeri Semarang \\ Semarang, Indonesia \\ mursid_ts@yahoo.co.id
}

\author{
Mardiana \\ Public Health Science Department \\ Universitas Negeri Semarang \\ Semarang, Indonesia \\ mardiana.ikm@gmail.com
}

\begin{abstract}
The fitness of an athlete is very important. Running athletes need enormous energy in a short time thereby they should increase the risk of anaerobic muscle fatigue. One of the effort to delay it was by increased of glycogen deposits and potassium intake which indicated to prevent and reduce anaerobic muscle fatigue. Palm date had relatively high content of carbohydrates and potassium. This study was aimed to determine the effect of palm date treatment to anaerobic muscle fatigue index (FI). It was one group pre-post test study design. The subjects were measured by RAST (Running-based Anaerobic Sprint Test) prior before any treatment as a pre-test. After one day rest, subjects received 100 grams of palm date treatment since one hour before RAST as a post-test. Data were analyzed by paired t-test. There was FI significant difference between pre-test and post-test $(\mathbf{p}<0.05)$. Palm date intervention was significantly prevented anaerobic muscle fatigue.
\end{abstract}

Keywords-anaerobe, carbohydrate, palm date, fatigue index (FI), RAST, running athlete

\section{INTRODUCTION}

Sport achievements has a high value for a country. The fitness of athletes before and during match is crucial to the sport achievement. Therefore, it becomes nutritionists concern in the sport nutrition field in order to improve athletes performance and sport achievement especially for running athletes to reduce the risk of fatigue. A running athlete requires great energy in a short time so the risk of fatigue is an aspect that truly needs attention. However, it is a blind spot that lacks of a serious preventive effort in fatigue management.

There are many terms that were understood by many people as well as the health and sport expert about the definition of fatigue. Physical fatigue can be interpreted as a decrease in work capacity caused by doing certain activity. Decrease in work capacity is decreased in quality and quantity of work or physical movement of a person[1]. While anaerobic fatigue is a muscle fatigue caused by high physical activity of anaerobic type which requiring rapid energy in a short time with the result of high lactid acid concentration in muscle cells[1]. High concentration of lactic acid in muscle cells trigger muscle fatigue that limits muscle ability to do contraction and cause pain[2]. Measument for anaerobic muscle fatigue can be performed using Fatigue Index (FI) parameter via Running-based Anaerobic Sprint Test $(\mathrm{RAST})[3,4]$.

One of alternative ways to delay anaerobic muscle fatigue during exercise is by increasing the amount of glycogen deposits of $25-100 \%$ derived from carbohydrate consumption before exercise[5]. This effort able to delay anaerobic muscle fatigue by $20 \%$ [2]. Macronutrient treatment such as carbohydrate to adult athletes as much as 30-80 grams per hour during sport exercise with duration $\geq 1$ hours can increase athletes endurance[6]. Muscle fatigue is also influenced by micronutrient substances, micronutrient studies suggest that increased activity of $\mathrm{Na}^{+}, \mathrm{K}^{+}$, and ATPase during exercise is able to stabilize the concentration of sodium and potassium in membrane to prevent fatigue[7]. Intervention study of carbohydrates and potassium food sources to athletes was indicated to give a positive effect in reducing anaerobic muscle fatigue[8]. One of high carbohydrate and calium food sources can be found in dried fruits. Palm date as one of dried fruits contains 73 grams carbohydrate and 698 miligrams potassium per 100 grams[9]. Therefore, palm date should be tested to ensure the effectiveness of these high carbohydrate and potassium food sources as anaerobic muscle fatigue prevention on athletes[8,10,11].

\section{MATERIALS AND METHODS}

Design of this study was one group pre-post test design. One group of subjects performed treatment with measurement before and after treatment. Study subjects were members of Center For Student Development and Training specifically for Running Athletic / Pusat Pelatihan Latihan Mahasiswa (PPLM) Atletik Lari, Sports Science Faculty, Universitas Negeri Semarang age 15-25 years. Samples were taken by simple random sampling and Slovin formula was used to sample calculation. 
Subject's inclusion criterias were not taking supplements, vitamins, high-dose minerals, herbs, medications associated with inflammatory reactions or immune function, not under physician care or postsurgery 6 months prior to the study and willing to follow the study through informed consent.

Subjects obligatory to fasting 8 hours before do the Running-based Anaerobic Sprint Test (RAST). On the first day, all of subjects were not given any food treatment then RAST was done as a pre-test. On the second day, subjects took a rest. Palm date treatment were done on third day as a post-test. Subjects received treatment of 100 grams of palm date since one hour before RAST[4].

The RAST was started by warming up approximately 10 minutes with stretching exercises and specific training routines (sprint and light running). It conducted on a straight 35 meters sprint track at each endpoint for escape. The test consisted of 6 sprints at maximum speed covering a distance of 35 meters, with a 10 -seconds pause between each trial.
Time was manually timed by a researchers, two other researchers were positioned at each extremity of the test area to control recovery time (10 sec)[4].

Peak Power Output (PPO) was calculated by body mass $(\mathrm{kg}) \mathrm{x}_{\text {distances }}{ }^{2}$ (meters) $\div$ time $^{3}$ (seconds). From the six sprint times and PPOs, it can be determined maximum and minimum power output. Then, Fatigue Index (FI) can be calculated by (maximum power output - minimum power output $) \div$ total time for the 6 sprints. Data were analyzed using paired t-test[4].

\section{RESULTS AND DISCUSSION}

\section{A. Subject Characteristics}

Subject characteristics were described in Table 1. Subjects had similar age characteristics among others. The youngest subject was 21 years old, while the oldest subject was 25 years old. Body Mass Index (BMI) ranges from $20.03 \mathrm{~kg} / \mathrm{m} 2$ to $23.91 \mathrm{~kg} / \mathrm{m} 2$.

TABLE 1. SUBJECT CHARACTERISTIC

\begin{tabular}{cc}
\hline Variable & Mean \pm SD \\
\hline Age $($ year $)$ & $22.83 \pm 1.10$ \\
Weight $(\mathrm{kg})$ & $64.47 \pm 3.65$ \\
Height $(\mathrm{m})$ & $1.70 \pm 0.03$ \\
Body Mass Index $\left(\mathrm{kg} / \mathrm{m}^{2}\right)$ & $22.26 \pm 1.12$ \\
Total Energy (calorie) & $2941.92 \pm 909.96$ \\
Total Carbohydrate $(\mathrm{gram})$ & $259.30 \pm 71.95$ \\
Total Potassium $(\mathrm{mg})$ & $1390.50 \pm 362.98$ \\
\hline
\end{tabular}

According to Table 2, subjects who suffered fatigue and not fatigue were $3(30 \%)$ and $7(70 \%)$ at pre-test (before palm date treatment), respectively.
Whereas, all of subjects at post-test (after palm date treatment) were not suffered fatigue at all.

TABLE 2. SUBJECT DISTRIBUTION BASED ON FATIGUE INDEX

\begin{tabular}{|c|c|c|c|c|c|c|}
\hline \multirow{3}{*}{ Measurement } & \multicolumn{4}{|c|}{ Fatigue Index $(\mathrm{FI})$} & \multirow[t]{3}{*}{ Total } & \multirow[t]{3}{*}{ Percent } \\
\hline & \multicolumn{2}{|c|}{$>10$ (Fatigue) } & \multicolumn{2}{|c|}{$\leq 10$ (Not Fatigue) } & & \\
\hline & Frequency & Percent $(\%)$ & Frequency & Percent $(\%)$ & & \\
\hline $\begin{array}{l}\text { Pre-test (before } \\
\text { palm date treatment }\end{array}$ & 3 & 30 & 7 & 10 & 10 & 100 \\
\hline $\begin{array}{l}\text { Post-test (after } \\
\text { palm date treatment }\end{array}$ & 0 & 0 & 10 & 100 & 8 & 100 \\
\hline
\end{tabular}

Table 3 showed that there was a significant difference of Fatigue Index (FI) between pre and post-test measurement $(\mathrm{p}<0.05)$. Means of FI at pre-test measurement was higher than at post-test. The results of this study indicated that Fatigue Index (FI) was lower at post-test after 100 grams palm date treatment than at pretest. The result of Paired t-test analysis showed that there was a significant difference of FI on both measurements.

TABLE 3. FATIGUE INDEX (FI) STATISTICAL TEST

\begin{tabular}{|c|c|c|c|c|c|c|c|}
\hline & \multicolumn{3}{|c|}{ Pre-test (before palm date treatment) } & \multicolumn{3}{|c|}{ Post-test (after palm date treatment) } & \multirow[t]{2}{*}{$p^{*}$} \\
\hline & Mean $\pm \mathrm{SD}$ & Min & Max & Mean \pm SD & Min & Max & \\
\hline $\begin{array}{l}\text { Fatigue } \\
\text { Index (FI) }\end{array}$ & $7.94 \pm 2.91$ & 4.88 & 13.05 & $3.82 \pm 1.33$ & 2.09 & 5.48 & 0.001 \\
\hline
\end{tabular}


Means of FI at post-test measurement was $3.82 \pm$ 1.33, whereas $7.94 \pm 2.91$ at pre-test. It could be interpreted that palm date treatment reduce FI on athletes moreover it proved the existing hypothesis. FI $\leq 10$ categorized that athletes did not experience fatigue, while FI > 10 means athletes were fatigue[10]. Running-based Anaerobic Sprint Test (RAST) was one of the tests for measuring anaerobic muscle fatigue that has been widely used because of its validity and reliability. It was more specific for anaerobic muscle fatigue tests in running based sports by looking at the FI[4].

In high-intensity sports activities such running, the body required energy rapidly and nutrient metabolism ran anaerobically. In such a situation, the body produced a side product of lactic acid that caused pain and muscle fatigue when accumulated[2]. Muscle fatigue was a condition that occurred after a strong or long muscle contractions which the muscle's ability to contract was decreased. It occurred for a certain period of time until muscle strength was restored[1].

Anaerobic energy metabolism consists of two systems, phosphocreatine (PCr) and anaerobic glycolysis systems known as the lactic forming system. Creatin $(\mathrm{Cr})$ was a type of amino acid stored in the muscle as a source of energy. Phosphocreatine (PCr) was a form of creatine that already phosphorylated in muscle. It was broken down into inorganic phosphate (PI) and creatine by creatinephospho kinase. PI bound the adenosine diphosphate (ADP) molecule to re-form adenosine triphosphate (ATP). High amount of energy (2.3 mmol ATP $/ \mathrm{kg}$ seconds) could be generated instantly to meet energy requirement for exercise with high intensity by PCr hydrolysis process[1]. However, it could only last about 7-10 seconds while doing the maximum physical activity because limited storage of ATP and creatine phosphate $(\mathrm{CP})$.

Another metabolism process was anaerobic glycolysis or known as the lactic forming system. This process used glucose deposits which largely derived from muscle glycogen and blood glucose to produce ATP. Basically, glucose was converted to pyruvic acid with the formation of ATP. Afterwards, pyruvic acid was converted into lactic acid in a limited oxygen condition or the formation of pyruvic acid occurred rapidly. If the supply of oxygen is insufficient, as in vigorously contracting skeletal muscles, the pyruvate cannot be oxidized further for lack of oxygen. The reduction of pyruvate by Nicotinamide Adenosin Dinucleotide Hydrogen (NADH) to form lactic acid was catalyzed by lactate dehydrogenase which forms the L-isomer of lactate. This condition occurred in severe contracting muscle such running, weighting, push-up, or long jumping. Lactic acid through the bloodstream circulated into the liver. Then, it was converted back into glucose. Glucose was circulated again into bloodstream and entered into muscle cells. Glucose was converted into glycogen which known as the lactic acid cycle or the Cory cycle[2].

The important nutrients that had a big role for anaerobic fatigue muscle were carbohydrate and potassium. Increased of glycogen storage for $25-100 \%$ derived from carbohydrate consumption before exercise was one effort to delay the occurrence of muscle fatigue during exercise. A study showed that this effort could delay muscle fatigue approximately $20 \%$ during exercise[2]. Moreover, a meta-analysis study recommended 30-80 grams of carbohydrate intakes to prolong the delay of muscle fatigue [6]. Date palm (phoenxdactylifera) was plant that had been known since antiquity, even before humans familiar with agricultural technology. Date palm was a very useful plant especially because of their resistance to high temperature and dry condition, even all of its part can be used for humans need. It was called by "adagium" as there were so many benefits of date palm as the number of days in a year[12].

Dried dates had an average water content of $22.5 \%$ with an energy content of $1151 \mathrm{Kj}, 73.5 \%$ carbohydrate, $0.45 \%$ fat, $1.9-2 \%$ protein, and $7.5 \%$ fiber[13]. In every 100 grams of palm date consist of 73 grams carbohydrate, 0.5 grams fat, 3 grams protein, and 3.7 grams fiber[9]. Another study of high carbohydrate food source was a banana treatment to athlete before exercise could significantly prevent muscle fatigue in the anaerobic phase[8]. The larger amount of glycogen reserve in muscle, it took longer time to spend it for activity. It determined muscle fatigue. When the glycogen reserved was run out, then the muscle would experience fatigue[14].

Muscle fatigue was also influenced by micronutrient substances. Micronutrient studies suggested that increased activity of $\mathrm{Na}^{+}, \mathrm{K}^{+}$, and ATPase during exercise was able to stabilize the concentration of sodium and potassium in membrane to prevent fatigue[7]. Each hundred grams of palm date consisted of $698 \mathrm{mg}$ potassium and $11 \mathrm{mg}$ sodium[9]. Potassium concentration in the intracellular fluid could increase 3060 minutes after consumption of high carbohydrate and potassium food sources[15]. A study of potassium contained in citrus fruits helped to maintain body fluid and acid balance. In addition, as important electrolyte for nerve impulses in muscle contraction and also maintain blood pressure[16]. Potassium requirement could be obtained from high potassium food sources such palm date, banana, and citrus. Potassium food sources consumption could prevent the occurrence of anaerobic muscle fatigue[8,10].

\section{CONCLUSION}

The study result found that there was a significant difference in mean fatigue index (FI) between pre-test (before palm date treatment) and post-test (after palm date treatment). Treatment 100 grams of palm date before exercise could reduce FI on athletes. Carbohydrate intake before exercise could prolong the delay of muscle fatigue. Moreover, potassium intake had a role for micronutrients concentration control in membrane to prevent fatigue.

\section{ACKNOWLEDGMENTS}

This study was in collaboration with Center For Student Development and Training / Pusat Pelatihan dan Latihan Mahasiswa (PPLM), Sport Science Faculty, Universitas Negeri Semarang. It funded by Sport Science Faculty, Universitas Negeri Semarang. The authors affirm no conflict of interest in this study. 


\section{REFERENCES}

[1] H. Hernawati, "Lactic acid production on aerobic and anaerobic exercises," FPMIPA UPI, pp. 1-2, 2013.

[2] M. A. Irawan, "Nutrition, energy, and sport performance," Polt. Sport Sci. Perform. Lab, vol. 1, pp. 1-13, 2007.

[3] A. Nummela, I. Hämäläinen, and H. Rusko, "Comparison of maximal anaerobic running tests on a treadmill and track," J. Sports Sci., vol. 25, no. 1, pp. 87-96, Jan. 2007.

[4] M. R. Queiroga, T. G. Cavazzotto, K. Y. Katayama, B. S. Portela, M. P. Tartaruga, and S. A. Ferreira, "Validity of the RAST for evaluating anaerobic power performance as compared to wingate test in cycling athletes," Motriz. Rev. Educ. Fis., vol. 19, no. 4, pp. 696-702, 2013.

[5] C. Chryssanthopoulos, C. Williams, A. Nowitz, and G. Bogdanis, "Skeletal muscle glycogen concentration and metabolic responses following a high glycaemic carbohydrate breakfast," J. Sports Sci., vol. 22, no. 1112, pp. 1065-1071, Nov. 2004.

[6] J. Temesi, N. a Johnson, J. Raymond, C. a Burdon, and H. T. O'Connor, "Carbohydrate ingestion during endurance exercise improves performance in adults," J. Nutr., vol. 141, no. 5, pp. 890-897, 2011.

[7] M. J. Mckenna, J. Bangsbo, and J. Renaud, "Fatigue mechanisms determining exercise performance muscle $\mathrm{K}+, \mathrm{Na}+$, and $\mathrm{Cl}-$ disturbances and $\mathrm{Na}+, \mathrm{K}+$ pump inactivation: implications for fatigue," J. Appl. Physiol., pp. 288-295, 2008.

[8] S. Kumairoh, "The effect of banana (musa paradisiaca) treatment on anaerob muscle fatigue among 'sepak takraw' athlete,” J. Nutr. Coll. Diponegoro Univ., pp.
$1-25,2014$.

[9] Erhart, Food composition data on "Nutrisurvey." Jakarta; Indonesia: Nutrisurvey for Windows [Univesitas Indonesia-SEAMEO TROPMED], 2005.

[10] E. Kusumastuti and N. Widyastuti, "The effect of sweet citrus juice (citrus sinensis) on anaerob muscle fatigue index among football athlete in 'Gendut Dony Training Camp (GDTC),”' J. Nutr. Coll., vol. 5, no. Jilid 4, pp. 368-373, 2016.

[11] R. R. Tanuwijaya, A. Kristiyanto, and M. Doewes, "The effect of brown sugar treatment on body fitnes," UNS, pp. 12-19, 2007.

[12] C. R. Zhang, S. A. Aldosari, P. S. P. V. Vidyasagar, P. Shukla, and M. G. Nair, "Health-benefits of date fruits produced in Saudi Arabia based on in vitro antioxidant, anti-inflammatory and human tumor cell proliferation inhibitory assays," J. Saudi Soc. Agric. Sci., vol. 16, no. 3, pp. 287-293, Sep. 2017.

[13] B. Caballero, L. Trugo, and F. Paul, Eds., Encyclopedia of food sciences and nutrition. London: Academic Press, 2003.

[14] E. Whitney and S. Rolfes, Understanding nutrition, 10th ed. USA: Thomson Learning, 2005.

[15] K. Miller, "Plasma Potassium Concentration and Content Changes After Banana Ingestion in Exercised Men,” J. Athl. Train., vol. 47, no. 6, pp. 648-65, 2012.

[16] H. R. Pohl, J. S. Wheeler, and H. E. Murray, "Sodium and potassium in health and disease," in Metal ions in life sciences, vol. 13, no. June 2017, A. Sigel, H. Sigel, and R. K. O. Sigel, Eds. Dordrecht: Springer Netherlands, 2013, pp. 29-47. 